\title{
Periodontal Disorder
}

National Cancer Institute

\section{Source}

National Cancer Institute. Periodontal Disorder. NCI Thesaurus. Code C63743.

An inflammatory process of the gingival tissues and/or periodontal membrane of the teeth, resulting in an abnormally deep gingival sulcus, possibly producing periodontal pockets and loss of alveolar bone support. 